\title{
New Traditions of the Social Process Management and Globalization Tendencies
}

\author{
Vladimir N. Ozeredenko* \\ Siberian Federal University \\ 79 Svobodny, Krasnoyarsk, 660041, Russia
}

Received 10.11.2014, received in revised form 17.12.2014, accepted 30.01.2015

\begin{abstract}
Reformation of the Russian political system is closelylinked with the socialtransformations characteristic of the contemporary world community that are a consequence of the globalization processes. Along with the natural globalization involving a natural human desire for integration we have witnessed the artificial globalization that poses a threat to the social and cultural identity of societies. That is why the solution to the problems of the modern education system takes into consideration the traditions characteristic of the Russian society.

To understand and solve this problem it is important to address the historical roots of the formation of the Russian consciousness, in which self-identity of our society occurred. Russia occupies a special position among the world's major civilizations. Its main feature is that in our country a triad "traditionculture-civilization" is not a unified, streamlined system that defines a common type of society. Both in the West and in the East a civilization obscures and conceals its non-identity of tradition by means of ideology, let alone culture; in both cases, the symbolic depth of experience is not opposed to the world of objectivity, a created civilization.
\end{abstract}

The objective of any system is self-preservation, a purposeful behaviour of the system aimed at achieving this goal and is a set of processes of interaction of various objects with each other, their mutual conditionality, and the change of a state. In this respect the social system appears as selfmanagement, an independent control of people over themselves, as the rule of the people-interaction of organizational forms of the system.

When considering the basic concepts that characterize the organization of society, the paramount importance is given to the issues of sustainability of social structures, sustainability of the social development. The experience of history shows that this sustainability is due to a number of reasons addressing the issues of social justice, goals and values of development. The notions of social justice are very delicate, but without their satisfactory solution there is no hope to build an adequate system of management, which would be the basis for sustainable development of society.

As the author points out, self-management and management are the parts of an integral unit, since any system is both a part and a whole. At the same time, the system as a part is controllable, but as a whole it is independent or self-managed. Independence should be relative, not absolute, because there are no completely independent systems in the world. As a whole, the system is independent, as a part, it is dependent on the superior system. Artificial deprivation of independence leads to its existence only as a part. The deviation in either direction leads the society to the dictatorship or anarchy.

The dialectical contradiction of an individual and a society is presented not only as a feature of perfection of a collectivist whole of Russia, but also as an indicator of the sustainability of society caused by identity of views and unanimity. These concepts are revealed as the dialectics of the one

(C) Siberian Federal University. All rights reserved

* Corresponding author E-mail address: Zan-3@mail.ru 
and the many, when the one assumes the many and the many assumes the one. Unanimity in such sense is not "uniformity" implying subordination of all the people to one will. Dialectical meaning of these concepts is to bring many wills to unity by matching them with each other, i.e. to find during the public discussion a general solution that is acceptable to the whole society.

As shown in the article, a principle of building of the corporate state was declared as corporatism; business owners and employees do not form two hostile classes, but corporations - work collectives, in which everyone work for the good of the nation in accordance with their positions - the highest value for the people. Generalization of the typical traditional forms of management shows that despite all the typicality of the main forms of the rule of the people, they have many basic features that are the result of traditions, history and mentality of a particular society. Management features specific to different societies have formed throughout the history of mankind and, therefore, have a socio-cultural appropriateness.

Keywords: form of management, world community, self-management, social transformation, social evolution.

Research area: philosophy.

The objective of any system is selfpreservation, a purposeful behaviour of the system aimed at achieving this goal and is a set of processes of interaction of various objects with each other, their mutual conditionality, and the change of a state. In this respect the social system appears as self-management, an independent control of people over themselves, as the rule of the people - interaction of organizational forms of the system.

Currently there is a huge number of sociological, political, anthropological, economic and historical works, in which traditions are considered as an inert force that must be overcome and broken to ensure the growth of modern structures. This approach cannot explain the specific parameters of the dynamics of modern differentiated political and economic structures, particularities of the positions of macrosocial groups of society, their internal dynamics and impact on the change in the way the elites behave [23].

In a rationalist version of social philosophy the society, the state is represented as the formation artificially created by human beings, their consciousness and will. A degree of optimality of such an artificial structure allegedly depends on how human nature is apprehended and how adequate the adopted and implemented community project is to it. The essences cognized by philosophy appear in this case as a norm, sample and ideal for the empirical reality. The element of utopianism becomes inevitable, which is essentially unhistorical, since the right public order that is relevant to the essence does not imply the history of its formation, but can be set up anywhere anytime. Overcoming this contradiction is possible when distinguishing between types of society (individualistic and collectivistic) and corresponding ideals of the social life [6].

We consider that social systems are complex dynamical systems, the basic concepts of which include the concept of purpose that essentially characterizes the social development. A.N. Whitehead writes: "There is an inevitable regularity in the fact that a civilization that does not have a higher purpose wallows in lust or falls into a monotonous uniformity that extinguish any living feeling" [29].

The problems related to the management of society were studied by a number of major researchers of the new wave who thoroughly study the processes taking place in various "sectors" of the social space. In particular, these are a situation in the field of demography (V. Tishkov), the study of 
the so-called political elite (O. Kryshtanovskaya), problems of corruption (G. Satarov), the state of public opinion (Yu. Levada, E. Bashkirova) the social changes in specific areas (M. Gorshkov), the Russian socio-political process (A.S. Panarin) and others.

It is no accident that the management issue is closely linked with the concept of justice. As you know, the issue of justice is a central theme of "The Republic" written by Plato, one of the subtitles of which is "On justice". One of the most detailed definitions of justice belongs to Karl Popper: "...Speaking of "justice” most of us, especially those who are committed to humanity, mean the following: (a) equal distribution of the burden of civil obligations, i.e. those restrictions on freedom that are needed in public life; (b) the equality of citizens before the law, of course, on conditions that (c) the laws are not biased in favour or against individuals, groups or classes; (d) fair trial and (e) the equal distribution of benefits (not just a burden) that for citizens can mean membership in this state" [25].

I. Milchin points to one of the paradoxes of confrontation of multiculturalism and maintenance of macro-identity by citizenship. It consists in the fact that it is the politics of identity that allows you to follow the classical principles of liberalism protecting the rights of the individual, while multiculturalism emphasizes the rights of groups and separates these groups from each other [19].

Ksenia Khvostova in her monograph [31] defines civilization as a collection of diverse links between the culturological, socio-economic, legal and political factors. The book includes modern theoretical ideas of hermeneutics, synergetics, modern intelligent globalism and comparative studies. For the first time the author examines in a new way the impact of ideas of the Eastern patristics on the development of society and the formation of the Byzantines' notions of the social and economic policy of the authorities and orientation in society.

At the same time, the nation-states are the major "players" in the global management. As the Japanese philosopher Nagata Hiroshi rightly pointed out, “...social groups, in whatever country and whatever the historical period they concentrated the power, did not neglect compiling chronicles and genealogies and corrected history attaching the case significance of the most important means of justification of their own power" [21]. However, in accordance with the dialectics of sameness and otherness, several generations of researchers strongly hold the idea that societies are different and are to be classified according to various criteria. Thus, they distinguished settled and nomadic societies, homogeneous and heterogeneous societies, traditional and anthropogenic societies, individualist and collectivist societies, etc. Besides individualist and collectivist societies become distinguishable, in particular, a civil society of a collectivist type and a civil society of an individualist type [34].

The principles of social management are based on a certain type of theorization, which in turn determines their hierarchy and content [20]. In this context, there is a natural necessity of distinguishing features of the social systems management in different types of society. In this regard V.L. Inozemtsev indicates that "democratic institutions characteristic of the Western society cannot function effectively in a segmented society that consists of various groups and associations..." [9]. And as the processes of segmentation, formation and legal registration of social groups that differ in their rights and duties are obvious, it can be assumed that their emergence and development is a direct reflection of the emergence and development of nondemocratic institutions" [35]. All this is reflected in the features of the public management. 
The new trends in social development caused by the formation of the information society require new concepts. In Soviet times, it was believed that in the twentieth century capitalism and socialism coexisted and fought one another. M. Antonov in his book [4] argues that the twentieth century was the century of corporate and totalitarian states that have already ceased to be capitalist, but they did not become socialist either. However, the world social science passed this fundamental fact and still perceives the world situation inadequately.

The harmony between an individual and society cannot be fixed, it cannot be static, but is possible only in dynamics, in dialectics of the unity of development (improvement) of the individual and society. "...Community of ancestral phenomena in symbolization systems and the field of pagan beliefs, the similarity of economic life that corresponded to geo-climatic conditions of habitats during the ethno-genesis of the Slavs, caused the basic principles of the original setting of the mentality of the Eastern Slavic peoples, which embodied certain features of interpretations of existential relations" [38].

The current conditions led to a crisis of traditional forms of management of public processes, which is largely determined by the crisis of fundamental ideologies: liberalism, progressism, rationalism and humanism. However, instead of turning to the analysis of the historical experience of managing different social systems, the deployment of globalization processes formed mythology designed not only to interpret everyday experience to the ordinary consciousness, as it was previously, but also using new possibilities and tools - to projectively "grow" the most incredible constructions, launching their magnificent kaleidoscope and, finally, denying any possibility of an ordinary individual to understand the reality [28]. It is this basis that forms a system of global management, global processes. The fact is that the value, consumer attitude to the maintenance of the world is one of the possible attitudes to it, and therefore such an attitude, which is traditional for the West, is not really acceptable in other parts of the world, especially where traditionally there is a more far-sighted attitude to the inner and outer world of people" [38].

Reformation of the Russian political system is closely linked with the social transformations characteristic of the contemporary world community that are a consequence of the globalization processes. Along with the natural globalization involving a natural human desire for integration we have witnessed the artificial globalization that poses a threat to the social and cultural identity of societies. That is why the solution to the problems of the modern education system takes into consideration the traditions characteristic of the Russian society.

Becoming a nature-forming factor a civilization accelerates all the processes so that the adaptive possibilities of society may not be sufficient to absorb the pace of these changes. The natural course of evolution of all self-developing and self-organizing processes is represented by a power function. For the past decades the social evolution has experienced radical metamorphoses transforming the majority of social relations from the material sphere into the non-material area - which is based on the information resource replacing raw materials and energy resources the basis of the previous stages of the civilization development.

It is known that there were two major obstacles for the economic activity of other nations: mentality (thinking, collective psychology and intensity of the spiritual life) and extremely harsh climatic conditions in the territory that is not suitable for living. The area with a rich nature became appealing to neighbouring countries once people built Russian cities, roads 
and communication systems, provided the basis of agriculture, industry, trade and scienceconsuming industry. After that, the Russian territories became the subject of geopolitical discords, trades, military aggression, peaceful expansion and diplomatic tricks [18].

As a rule, it is this fact that is not taken into account when the question of reformation of the system of power in Russia is raised. That is why when considering the features of functioning of the self-management system it is important to distinguish between the institutional and functional content of the unity of the civilization and culture, in general, it is not possible to waive the dialectics of the individual and the common, the dialectics of a structure and a function and so on. Aristotle offers a special method of deviation for the study of the state system. Currently, this method is especially important, and not only in political science. It is designed to study the dynamics of the amplitudes of possible deviations of the system from some standard, steady state taking into account the capabilities of the system to independently go back to its normal functioning, to return to this stationary state by its own efforts, to overcome the cost of deviations from the specified state, to compensate for expenses, to avoid cases of decompensation.

The specifics of the historical consciousness of the Russian society is realized in the following aspects: the Byzantine tradition of religious understanding of the historical life; historical identity of the Russian people beginning with Peter the Great, in conjunction with elements of imitationoftheWesternculture; theoreticalattitude to history formed into an independent historical science; imperial historical consciousness born out of a situation of confrontation of Napoleonic France [3].

There are a lot of myths about Russia, bases of which are someone's opinions caught up and seen as a result of an in-depth analysis. Obviously, this was largely due to the fact that "philosophy in our country, its being is too dependent on the quirks of a bureaucratic mind" [26]. But there is always a reason for everything; however, it is known that the mythological thinking is replaced by the philosophical one. This should be considered in the process of reforming the administrative structures of the country.

N.O. Lossky in the chapter "Characteristics of Russian philosophy" of "History of Russian philosophy", in terms of his cosmological approach to examining the philosophy functions, states that in contrast to the special sciences, i.e. sciences of particular sections and aspects of the world, philosophy bears a character and interests of the various peoples who were engaged in it. Therefore, we can talk about national peculiarities of the German, French, English, American and Russian philosophy [16]. For example, "a Russian civilization and Russian culture is a "rhizome". It refers to a variety of different phenomena that are not subject to any unity and are characterized by heterogeneity, equality, mutual disruptiveness and interconnection, spontaneous variability and autonomy. At this, rhizome disruptiveness is recognized as "insignificant"; its heterogeneity, explaining the ruptures, does not exclude the interconnection of equal parts; the interconnection does not reject autonomy and equality, and the variability does not lead to unity, but enhances ruptures and autonomy of elements of the whole" [7]. The location of Russia between the East and the West, in fact, creates its specific "rhizomeness" that is not reducible to any common denominator - neither European nor Asian [13].

In the process of reformation of social institutions in Russia it is important to take into account that history has repeatedly denied futile attempts to "copy" culture and ideology of Russia in a Western style, and every time these attempts were doomed to failure and brought innumerable 
suffering to the Russian people. The fact is that the Russian and Western cultures are incompatible and are fundamentally different from each other because they belong to different types of society. Having made this conclusion, we got added evidence of the relevance, efficiency and deep validity of the difference between the collectivist and individualist types of society, as well as the validity of the study of the Russian society as a collectivist one.

However, when creating a modern system of self-management in Russia, it is important to consider that the following values of the Russian spiritual culture collapsed in the last decade in Russia:

- common consciousness through the introduction of the unlimited cult of individualism;

- replacement of the traditional priority of the productive labour in the interests of the Motherland in Russian culture by the service to the unknown motherland on the principle of priority of consumerism and commercialism;

- replacement of the authority of the public interest by the personal interest, of the Russian humanity by the universal humanity from the perspective of cosmopolitanism;

- replacement of friendship and brotherhood of the peoples of Russia by the ethnic strife;

- replacement of patriotism and love for the country by the service to the unknown motherland or the "world" management.

To understand the impact of globalization on the Russian person, it is important to take into account the fact that "all the characteristic features of the Russian people say that he is unable to naturally fit in the modern consumer civilization and mass culture. Because the Russian person cannot be entirely inspired by the ideals of enrichment and consumption, which are the main drivers of the modern civilization" [1].

We can say that the most valuable and fruitful ideas of the leading Russian thinkers are in the doctrine of conciliarism. It is known that one of the cornerstones of the "Russian cosmism" is the concept of a symphonic personality, which is based on the concept of conciliarism developed as "one of the most important theoretical considerations of the Old Russian philosophy". Conciliarism is understood "as a characteristic of the universal connection of the social phenomena. It deciphers the human world as a certain mosaic...” [33], pieces of which are individuals, communities and social phenomena.

Conciliarism means a combination of freedom and unity of many people through their shared love for the same absolute values. It was clear that this idea could be used to resolve many difficult problems of social life. The principle of conciliarism means that neither a patriarch having supreme authority nor the clergy, nor even an ecumenical council are the carriers of the absolute truth. In turn, the conciliar state cannot overrule over the spiritual authority, in order not to eviscerate the rules of law, not to undermine the importance of moral, ethical, ideological, religious and other norms, not to destroy the institutional harmony of the collectivist society.

The people who took over the care of spirituality, involving not care of the real, but of the perfect, the ideal, cannot but carry a utopian consciousness that sometimes helps them survive in hard times, but sometimes destroys them. Utopianism and the associated romanticism, trustfulness in the high word encouraged Russian thinkers to seek the truth of life either in the future (Westernistic utopias of communism and a democratic paradise) or in the past (Slavophile utopias of returning to the blessedness of the pre-Petrine, traditional Russian life). God-manhood and conciliarism 
are the ideas that are unrealizable to their final limit, but they are not abstractedly speculative inventions of a philosophizing dreamer, but are quite active factors for the spiritual unity of the nation [14].

The article of V.K. Egorov titled "Philosophy of culture and debates about the processes of globalization", O.N. Astafieva's "The diversity of models of ethnic and cultural identity in the modern information and communication space" and V.N. Dakhin's "Globalization and cultural and ideological crisis of the modern world" reveal the globalization conflicts in the field of cultural and ideological processes. V.K. Egorov draws attention to the fact that in connection with the deepening process of globalization the question of universal culture is being rethought at the philosophical and methodological level. "The universal" that is understood as something somehow selected by someone, standardized and adopted as the standard is the death of culture and human civilization, since it involves averaging that excludes diversity, as well as multicreativity, which is the essence of culture and a source of its development" [8].

The article of O.N. Astafieva discusses the following topics: whether the world, in terms of establishing of a new kind of society - information and a new order, can maintain ethnic and cultural diversity; what the mankind should do: whether to increase the distance between cultures by strongly encouraging the desire to preserve identity, whether to strengthen expansion and the processes of unification of cultures in order to achieve a certain cultural and civilizational level or, on the contrary, to reduce the differences between cultures at the expense of their adaptation to the changing conditions [5].

In the book "The historical process and management of society" V.S. Diev says: "The development of society is a natural historical process. At the same time in an individualist society it is a process of satisfaction of the needs of individuals, their activity in the aggregate is a certain way to block abnormalities, a specific norm of implementation of its natural historical process. However, the collectivist society by the essence of its activity is aimed to ensure that the life-affirming social relations that help block abnormalities of the natural historical process prevail. And so it appears that the collectivist society requires a fundamentally different form of implementation of the natural historical process" [10]. In this regard, V.A. Kapranov stressed that Russia is destined to be the spiritual leader of the world, because no one except Russia can lead the spiritual renewal of humanity [11].

A. Etzioni proves that the East is moving towards the Western model (although many people believe it is a matter of course). In fact, it goes to some intermediate position. "The same thing happens with the West that is moving towards the East - but not to the East as such, but through the reduction of the deficit of community (and the authority of power) to some medial state... It should also be noted that the movement takes place not in the direction of a united synthetic model. On the contrary, a number of social projects that have two important things in common are being implemented: the society is becoming more balanced than in the individualist or authoritarian variants, and the public order is based on the power of persuasion more than in any of these cases" [36].

The experience of modernity reveals a new human form, a new anthropological reality devoid of immutable essential nucleus. This form is fundamentally at odds with the traditional European views of a human. A human of the turn of the millennia, of the time of psychoanalysis and the Internet, of the recent totalitarian experience, of the radical psychotechnical, psychedelic, virtual practices, of the gender revolutions that person cannot be considered as the same 
classical subject of the European anthropology and metaphysics [32].

The basic idea underlying the new approach to politics is that if an individual choice and its results are not subject to control by the society, the rules that are followed when making the choices are available for it and, therefore, they can be changed through the collective efforts of the individuals that make up a civil society [27].

Understanding of the modern essence of the self-management system implies recognition of the fact that Russia is a part of humanity, and humanity has entered a stage of systemic civilization crisis, which is fraught with a bifurcation with an unpredictable outcome. Russia, as the other countries, will have to solve the problem of a global scale - search for ways to prevent the possible destruction of mankind. "Russia gave the world a constellation of the great exponents of conscience and justice... Let us also remember that the whole history of Russia and its culture is coloured with the desire and the right to assert that Russia can and should take the burden of "the one invoking" the humanity to unite in overcoming the crisis and preventing the loss of civilization, should raise the banner of renewal of humanity and not lower it. This idea can be accepted by the Russian people, can unite the people if to reveal the true state of affairs and the threat of total destruction. To achieve the target underlying this idea, people will agree to work and endure. This goal will change people's understanding of their belonging to society. It will identify the main priorities in the actions of the authorities and contribute to the cooperation between Russia and other states. The chances of a co-evolutionary path of development of human society, the only possible way forward, will increase" [37].

Withdrawal from the total crisis of the world civilization is in the spiritual reformation, in the gradual transition to another global system of values ("ideational" by Pitirim Sorokin). The world community faces the task -to build a spiritual hierarchy instead of a consumer horizontal, to express a new future in the language of their own spiritual tradition, to offer the world that is in search of a global revolution of consciousness a post-consumer, post-technical, post-economic alternative" [22].

In the global world people must study the laws of the object development together with its security laws, which implies the emergence of not just a science of security, but a science of connection of security and development. It is included in the field of research, which is called noospherology, in which the problems of ensuring security and sustainable development are organically fit into [30].

Russia, despite its own characteristics, being an integral part of the world civilization, will accumulate positive experience of democratic development. The Russian state will not only be responsible for this, but will also transform in accordance with the requirements and principles of the new order of civilization, thereby contributing to the development of the world as a whole. For example, in the "Conception of social and economic development of Russia until 2020" adopted by the Russian government in November 2008, the future development is seen mainly as an innovative, socially oriented development. The innovative, socially oriented development emphasizes those aspects that are the most important for the transition to a more balanced, sustainable development of our country. Sustainable development is a more holistic evolutionary system than the above mentioned innovative, socially oriented development. This is the last component of the future "sustainable evolution" of humanity that is the most relevant in the current Russian conditions. However, in modern Russia in the conditions of global economic crisis the withdrawal from it, in the 
long term, is seen through the transition to a sustainable future, but only if the Strategy-2020 is implemented (i.e. the same period as the abovementioned Conception). After the transition period from a planned to a market economy sustainable development is the very innovation and strategic goal of the next stage of development of not only Russia but also of the whole world community. This type of development is oriented toward our common long-term future, crisis-free and balanced, secured society. The alignment of different accents of the Strategy-2020 and the Conception-2020 is caused not only by the fact that they were prepared by different "teams", but also by certain objective circumstances. One (strategy) focuses on security issues (conservation), while the other (conception) - on the problems of development, for which there are although related, but not completely matching strategic national priorities. These priorities had to be connected in such a way that they not only would not contradict each other, but also would create a system-synergetic effect necessary for the transition to a sustainable future.

Mankind has come to an alternative: either the "graveyard of humanity" or a way out to the path of harmonious development with nature. Therefore, we cannot totally agree with a statement that is widespread among the market economists that we currently have "to rely on the development that is independent of the conscious control more than ever". And the result of the conscious, science-based choice should be movement toward a planned economy. Thus, the implementation of the civilization plan requires the scientific prediction and planning of socioeconomic development based on it [24].

The liberalization of the world that made the free movement across national borders possible for the intellectual elite and globalization that, in turn, made the free movement of capital and technology possible, lead to the concentration of the main resources of the information age in the most-favoured economic areas [15].

In general, the humanities voluntarily and according to their capabilities fulfilled the function imputed by the perestroika ideologists for transformation of the public consciousness of the Russian society to the limit, beyond which their impact ends hinging on the transcendence and mental characteristics of society going to the Orthodox tradition [17]. In particular, understanding of the mechanism of activity of the information and tectological spirituality is an important and necessary condition for the understanding of the social structure, which determines the specifics of practical changes and optimization of social relations. This is especially important and necessary for the establishment of not only the so-called "sustainable development of society" or the global or antiglobal development of society, but also for the establishment of natural, cosmo-appropriate perfection of society as a harmonized space of human existence [12].

Sacred purposes and destinies of the traditional continental empires supporting a universal-historical model were replaced by the civilizing missions of the colonial empires [2]. Civilizational differences between the mother countries and the colonies were explained in the evaluation terms by underdevelopment and the phased lag of the latter quite fitting into the required difference of levels of development of the centre and the suburbs so characteristic of the empire.

Thus, the reformation of the Russian political system involves the analysis of the following important aspects. Firstly, the need to consider the origins of the Russian statehood, as well as the features of selfmanagement require to proceed from the fact that the idea of unity is at the forefront of the Russian scientific and philosophical belief system and allows us to view the world and its 
fundamental laws as the indivisible whole. An alternative approach grounded in the works of the Russian cosmists performs an ideological and methodological function restoring the connection in the system of social and philosophical knowledge, which is crucial for the development of new management systems in the context of globalization.

\section{References}

1. Aksyutchits, B. Apologiya russkogo kharaktera [Apology of the Russian character] V. Aksyuchits, Nezavisimaya Gazeta. 2000 . June 27.

2. Alaev, L.B. Imperiya: Fenomen ili tip razvitiya? [Empire: a phenomenon or a type of development?] Issues of history. 2000. № 4-5.

3. Andreev, A.L. Osobennosti russkogo istoricheskogo samosoznaniya [Features of the Russian historical self-consciousness]. A.L. Andreev. Theory and History. 2004. № 3.

4. Antonov, M. Ot lzhekapitalizma k totalitarizmu! (Mir v XXI veke i sudby Rossii) [From pseudo-capitalism to totalitarianism! (The world in in the $21^{\text {st }}$ century and the fate of Russia)] M. Antonov. M: Alta-print, 2008.

5. Astafieva, O.N. Mnogoobrazie modeley etnokulturnoi identichnosti v sovremennom informatsionno-kommunikativnom prostranstve [The variety of models of ethnic and cultural identity in the modern information and communication space]. Globalization and perspectives of the modern civilization. Ed. by K.Kh. Delakarov. M: KMK, 2005. P. 106.

6. Churinov, N.M. Sovershennaya lichnost i lichnost svobodnaya [A perfect personality and a free personality] N.M. Churinov. Theory and History. 2005. № 1. P. 55.

7. Churinov, N.M. Sovershenstvo $i$ svoboda [Perfection and Freedom] N.M. Churinov. Krasnoyarsk, 2001.

8. Deleuze, G., Guattari, F. Rizoma. Vvedenie [Rhizome. Introduction]. G. Deleuze, F. Guattari. Kornevishche Ob. The book of a non-classical aesthetics. M, 1998.

9. Egorov, V.K. Filosofiya kultury i diskussii o protsessakh globalizatsii [Philosophy of culture and the discussion about the processes of globalization]. Globalization and perspectives of the modern civilization. Ed. by K.Kh. Delakarov. M: KMK, 2005. P. 104.

10. Etzioni, A. Ot imperii $k$ soobshchestvu: noviy podkhod $k$ mezhdunarodnym otnosheniyam [From empire to community: a new approach to international relations] A. Etzioni. M: Ladomir, 2004. P. 44.

11. Inozemtsev, V.L. Immigratsiya: novaya problema novogo tysyacheletiya. Metodologicheskiye aspekty [Immigration: the new challenge of the new millennium. Methodological Aspects]. V.L. Inozemtsev. Sociological studies. 2003. № 6. P. 35.

12. Kalashnikov, V.D. Nauchnaya teoriya i nauchnaya istoriya [Scientific theory and scientific history] V.D. Kalashnikov. Theory and History. 2002. № 1. P. 55.

13. Kapranov, V.A. Nravstvenniye osnovy russkogo dukha [The moral foundations of the Russian spirit]. V.A. Kapranov. Russia: the Past, the Present, the Future. Materials of the All-Russian scientificpractical conference. December 16-19, 1996. Saint-Petersburg. SPb., 1996.

14. Khoruzhy S.S. Chelovek i ego tri dalnikh udela. Novaya antropologiya na baze drevnego opyta [A man and his three distant inheritances. The new anthropology based on ancient experience]. Problems of Philosophy. № 12003. 
15. Khvostova, K. Vizantiyskaya tsivilizatsiya kak istoricheskaya paradigma [Byzantine civilization as a historical paradigm] K. Khvostova. St. Petersburg: Aletheia, 2009.

16. Kolmakov, V.Yu. Dukhovno-informatsionnaya tektologiya kultury [Spiritual and information tectology of culture. V.Yu. Kolmakov. Theory and History. 2004. № 3. P. 138.

17. Kondakov, I.V. "Po tu storonu" Evrpy" ["On the other side" of Europe"] I.V. Kondakov. Problems of Philosophy. 2002. № 6.

18. Korolkov, A.A. Dukhovniy smysl russkoi kultury [The spiritual meaning of the Russian culture]. St. Petersburg: Publishing House of Herzen State Pedagogical University of Russia. 2006. P. 246.

19. Kudashov, V.I. Russkiy mir i natsionalnaya ideya [Russian world and the national idea] Theory and History. № 2, 2003. P. 49-50.

20. Lossky, N.O. Istoriya russkoi folosofii [History of Russian Philosophy] Lossky. M: Sovetskiy pisatel, 1991.

21. Martseva, L.M. Osobennosti khozyaistvennogo osvoeniya prostransvenno-vremennykh granits rossiyskoy tsivilizatsii [Features of the economic development of spatial and temporal boundaries of the Russian civilization] (Experience of comparison). L.M. Martsevo. Theory and History. 2002. № 1 .

22. Martseva, L.M. Sushchnost i sushchestvovanie truda [The essence and the existence of labor]. Selected articles. Omsk: IC “Omsk Scientific Bulletin”, 2013. P. 95. 400 pp.

23. Milchin, I. Kultura kak factor amerikanskogo globalnogo vliyaniya [Culture as a factor of the American global influence] I. Milchin. Philosophical Sciences. 2003. № 3. P. 39.

24. Morozova, O.F. Tipologiya sotsialnogo upravleniya i metodologiya [Typology of social management and methodology] O.F. Morozova. Theory and History. 2004. № 3. P. 89.

25. Nagata, H. Istoriya filosofskoi mysli Yaponii [History of a philosophical thought in Japan] H. Nagata. M: Progress, 1991. P. 108.

26. Osipov, G.V. Sotsiologicheskoe ponimanie novykh geopoliticheskikh i sotsialnykh realiy v XXI veke [The sociological understanding of the new geopolitical and social realities in the $21^{\text {st }}$ century] The Bulletin of RFS-№ 3 -2005.

27. Ploskonosova, A.P. Rol pravyashchei elity v rekonstruktsii sotsialnoy realnosti [The role of the ruling elite in the reconstruction of social reality] A.P. Ploskonosova. Philosophical Sciences. 2005. № 12. Р. 53.

28. Popper, K. Otkrytoe obshchestvo i ego vragi [The open society and its enemies] K. Popper. M., 1992. P. 126.

29. Porus, V.N. Filosofskiy congress dolzhen pomeshat raspadu rossiyskoi filosofii [The philosophical congress should prevent the disintegration of Russian Philosophy]. V.N. Porus. The Bulletin of RFS. 2004. № 2.

30. Pozdnyakov, A.V. "Ustoichivoe razvitiye, singulyarnye tendentwii $i$ rol nauki $v$ razvitii tsivilizatsii" ["Sustainable development, singular trends and the role of science in the development of civilization"], the Institute of Optical Monitoring SB RAS, Tomsk, 2002.

31. Rusakov, V.M. Problema ratsionalnogo $i$ irratsionalnogo v sovremennoi filosofii [The problem of the rational and the irrational in modern philosophy] V.M. Rusakov. Bulletin of the Russian Philosophical Society. 2003. № 1. P. 33. 
32. Ruzavin, G.I. Teoriya ratsionalnogo vybora $i$ granitsy ee primeneniya $v$ sotsialnogumanitarnom poznanii [The theory of rational choice and the limits of its use in the socio-humanitarian cognition] Problems of Philosophy № 5-2003. P. 65.

33. Shipilov, A.V. Sudba demokratii v epokhu globalizatsii [The fate of democracy in the age of globalization] A.V. Shipilov. Philosophical Sciences. 2005. № 11. P. 32.

34. Ursul, A.D., Ursul T.A. and others. Ustoichivoe razvitiye, bezopasnost, noosferogenez. [Sustainable development, security, noospherogenesis]. Moscow, 2008.

35. Verkhovtseva, T.E. Sobornost: russkaya traditsiya i russkiy ideal [Conciliarism: the Russian tradition and the Russian ideal]. T.E. Verkhovtseva. Theory and History. 2004. № 3. P. 86.

36. Whitehead, A.N. Selected works on philosophy. A.N. Whitehead. M, 1990. P. 482.

37. Yakhnin, E.D. Evolyutsiya $i$ budushcheye chelovecheskogo sotsiuma (obshchenatsionalnaya ideya Rossii v mirovom kontekste) [The evolution and future of human society (national idea of Russia in the global context)] WF-2006-№ 5. P. 174.

38. Yatsenko, M.P. Istoricheskiye aspekty globalizatsii kak upravlyaemogo protsessa [Historical aspects of globalization as a managed process]. Bulletin of Oryol State University. Series: New Humanities research. 2011. № 5 (19). P. 226.

39. Yatsenko, M.P., Malinin, A.V. Problema sovershenstva v kontseptsii russkogo kosmizma [The problem of perfection in the concept of Russian cosmism]. Scientific opinion. Scientific Journal. 2012.

№ 12. P. 24.

\section{Новые традиции управления \\ общественными процессами}

и глобализационные тенденции

В.Н. Озереденко

Сибирский федеральный университет

Россия, 660041, Красноярск, пр. Свободныгй, 79

Реформирование российской политической системь тесно связано с социальными трансформациями, характерными для современного мирового сообщества, которые являются следствием глобализаиионных процессов. Наряду с естественной глобализацией, предполагающей закономерное стремление человечества к интеграчии, мы стали свидетелями искусственной глобализаџии, несущей угрозу социокультурной идентичности социумов. Именно поэтому решение проблем современной системы образования предполагает учет традиций, характерных для российского общества.

Для понимания и решения указанной проблемы важно обратиться к историческим корням формирования российского сознания, в которых происходила самоидентификация нашего общества. Россия занимает совершенно особенное положение в ряду важнейших мировых циивилизаций. Главная ее особенность состоит в том, что триада традиция - культура цивилизация в нашей стране не составляет единой отлаженной системы, определяюшей и общий тип общества. И на Западе, и на Востоке ичивилизачия средствами идеологии затушевывает и скрадывает свою нетождественность традиции и тем более культуре; в 
обоих случаях символическая глубина опыта не противопоставляется и не противостоит миру предметности, созидаемой цивилизацией.

Целью любой системы является самосохранение, поведение системы, направленное на достижение этой ияели и представляющее собой совокупность проиессов, а также взаимодействие различных объектов, их взаимную обусловленность, изменение состояния. В этом отношении социальная система выступает как самоуправление, самостоятельное управление народа самим собой, как народовластие - взаимодействие организационных форм данной системы.

При рассмотрении базовых понятий, характеризующих вопросы организации жизни общества, первостепенное значение приобретают вопросы устойчивости соииальных структур, устойчивости социального развития. Опыт истории говорит о том, что эта устойчивость обусловлена рядом оснований - решением вопросов о соииальной справедливости, целях и иенностях развития. Представления о сочиальной справедливости весьма деликатны, но без их приемлемого решения нельзя надеяться на построение адекватной системы управления, которое стало бы основой устойчивого развития общества.

Как указывает автор, самоуправление и управление - это части одного целого, так как любая система является одновременно и частью, и цельм. При этом как часть система управляема, а как иелое - самостоятельна или самоуправляема. Самостоятельность должна быть относительной, а не абсолютной, поскольку в мире не существует абсолютно самостоятельных систем. Как иелое система самостоятельна, как часть зависит от вышестоящей системы. Искусственное лишение системы самостоятельности ведет ее к существованию только как части. Отклонение в ту или иную сторону направляет общество к диктатуре или анархии.

Диалектическое противоречие личности и общества предстает не только как характеристика совершенства коллективистского целого России, но и как показатель устойчивости общества, обусловленной единомыслием, единоумием и единодушием. Данные понятия раскрываются 6 качестве диалектики единого и многого, когда единое предполагает многое, а многое -единое. Единомыслие в таковом значении представляет собой не «единообразие», предполагающее подчинение всех людей одной воле. Диалектический смысл данных понятий заключается в приведении к единству многих воль посредством согласования их между собой, т.е. в стремлении найти в процессе всенародного обсуждения общее решение, приемлемое для всего общества.

Как показано в статье, приниииом построения корпоративного государства был объявлен корпоративизм; хозяева предприятий и наемные работники образуют не два враждебных класса, а корпорации - трудовые коллективы, в которых все в соответствии со своим положением трудятся на благо начионального государства - этой высшей ценности для народа. Обобщение типичных традиционных форм управления показывает, что при всей типичности основных форм народовластии они имеют много принципиальных особенностей, являющихся следствием традиции, истории и менталитета конкретного социума. Черты управления, характерные для различных обществ, сформировались на протяжении всей истории человечества и поэтому обладают социокультурной целесообразностью.

Ключевые слова: форма правления, мировое сообщество, самоуправления, социальные трансформации, сочиальная эволющия.

Научная специальность: 09.00.00 - философские науки. 